MAKALAH

\title{
ARGUMEN TENTANG TANTANGAN TERHADAP PANCASILA SEBAGAI IDEOLOGI NEGARA
}

RINA VIONITA

Rinavionita07@gmail.com

20220130

" STIE AKBP KBP PADANG “

\section{A. PENDAHULUAN}

Lahirnya ketentuan dalam Pasal 35 ayat (5) Undang-Undang Nomor 12 Tahun 2012

menyatakan bahwa kurikulum pendidikan tinggi wajib memuat mata kuliah pendidikan agama,pendidikan Pancasila, pendidikan kewarganegaraan, dan bahasa Indonesia, menunjukkan bahwa Negara berkehendak agar pendidikan Pancasila dilaksanakan dan wajib dimuat dalam kurikulum peguruan tinggi sebagai mata kuliah yang berdiri sendiri. Dengan demikian, mata kuliah pendidikan Pancasila ini dapat lebih fokus dalam membina pemahaman dan penghayatan mahasiswa mengenai ideologi bangsa Indonesia. Artinya, pendidikan Pancasila diharapkan menjadi ruh dalam membentuk jati diri mahasiswa dalam mengembangkan jiwa profesionalitas mereka sesuai dengan bidang studi masing-masing. Selain itu, dengan mengacu kepada ketentuan pasal 2 Undang-Undang Nomor 12 Tahun 2012, sistem pendidikan tinggi di Indonesia harus berdasarkan Pancasila. Implikasinya, sistem pendidikan tinggi di Indonesia harus terus mengembangkan nilai-nilai Pancasila dalam berbagai segi kebijakannya dan menyelenggarakan mata kuliah pendidikan Pancasila secara sungguh-sungguh dan bertanggung jawab.

Mahasiswa diharapkan dapat menguasai kompetensi: bersyukur atas karunia kemerdekaan dan Pancasila sebagai dasar negara Indonesia; menunjukkan sikap positif terhadap pentingnya pendidikan Pancasila; menjelaskan tujuan dan fungsi pendidikan Pancasila sebagai komponen mata kuliah wajib umum pada program 
diploma dan sarjana; menalar dan menyusun argumentasi pentingnya pendidikan Pancasila sebagai komponen mata kuliah wajib umum dalam sistem pendidikan di Indonesia. Urgensi pendidikan Pancasila bagi mahasiswa sebagai calon pemegang tongkat estafet kepemimpinan bangsa untuk berbagai bidang dan tingkatan, yaitu agar tidak terpengaruh oleh paham-paham asing yang negatif.

Mata kuliah pendidikan Pancasila adalah usaha sadar dan terencana untuk mewujudkan suasanabelajar dan proses pembelajaran agar mahasiswa secara aktif mengembangkan potensi dirinya untuk memiliki pengetahuan, kepribadian, dan keahlian, sesuai dengan program studinya masing-masing. Dengan demikian, mahasiswa mampu memberikan kontribusi yang konstruktif

dalam bermasyarakat, berbangsa, dan bernegara, dengan mengacu kepada nilai-nilai Pancasila. Hal ini berarti mata kuliah Pancasila merupakan proses pembelajaran dengan menggunakan pendekatan student centered learning, untuk mengembangkan knowledge, attitude, dan skill mahasiswa sebagai calon pemimpin bangsa dalam membangun jiwa profesionalitasnya sesuai dengan program studinya masing-masing, serta dengan menjadikan nilai-nilai Pancasila sebagai kaidah penuntun (guiding principle) sehingga menjadi warga negara yang baik .

Abdulganii menyatakan bahwa Pancasila adalah leitmotive dan leistar, dorongan pokok dan bintang penunjuk jalan. Tanpa adanya leitmotive dan leitstar Pancasila ini, kekuasaan negara akan menyeleweng. Oleh karena itu segala bentuk penyelwengan itu harus dicegah dengan cara mendahulukan Pancasila dasar filsafat dan dasar moral (1979:14). Agar Pancasila menjadi dorongan pokok dan bintang penunjuk jalan bagi generasi penerus pemengang estafet kepemimpinan nasional, maka nilai-nilai Pancasila harus dididikan kepada para mahasiswa melalui mata kuliah pendidikan Pancasila. 


\section{B. PEMBAHASAN}

Pengertian Pancasila Sebagai Ideologi Negara

Pancasila sebagai ideologi negara artinya seluruh warga negara Indonesia menjadikan pancasila sebagai dasar sistem kenegaraan. Nilai-nilai yang ada pada setiap butir pancasila harus dijadikan sebagai pedoman dasar dalam melangsungkan kehidupan bernegara. Selain itu, pancasila sebagai ideologi negara juga bermakna menjadikan pancasila sebagai cita-cita atau visi. Hal ini tentunya berlaku untuk pemerintah dan seluruh warga negara. Pada hakikatnya pancasila sebagai ideologi negara memiliki tiga dimensi sebagai berikut:

- Dimensi realitas, suatu ideologi harus mampumencermnkan realitas yang hidup dan berkembang dalam masyarakat oleh karena itu Pancasila selain memiliki dimensi nilai-nilai ideal normatif, maka Pancasila harus dijabarkan dalam kehidupan nyata sehari-hari baik dalam kaitannya bermasyarakat maupun dalam segala aspek penyelenggaraan negara. Dengan demikian Pancasila sebagai ideologi terbuka tidak bersifat 'utopis' yang hanya berisi ide - ide yang mengawang, namun bersifat realistis artinya mampu dijabarkan dalam kehidupan yang nyata dalam berbagai bidang (Kaelan, 2016, 117)

- Dimensi idealitas; mengandung cita-cita yang ingin dicapai dalam berbagai bidang kehidupan bermasyarakat, berbangsa,dan bernegara. yaitu nilai-nilai dasar yang terkandung dalam Pancasila yang bersifat sistematis dan rasional 
yaitu hakikat nilai-nilai yang terkandung dalam lima sila: ketuhanan, kemanusiaan, persatuan, kerakyatan dan keadilan, maka dimensi idealis Pancasila bersumber pada nilai-nilai filosofis yaitu filsafat Pancasila. Oleh karena itu dalam setiap ideologi bersumber dari pandangan hidup nilai- nilai filosofis (Poespowardoyo dalam Kaelan, 2016, 116);

- Dimensi fleksibilitas; mengandung relevansi atau kekuatan yang merangsang masyarakat untuk mengembangkan pemikiran-pemikiran baru tentang nilai-nilai dasar yang terkandung di dalamnya.

Pacasila sebagai ideologi negara memiliki peran yang konkret sebagai berikut:

- Sebagai penuntun warga negara, artinya setiap perilaku warga negara harus didasarkan pada preskripsi moral.

- Sebagai penolakan terhadap nilai-nilai yang tidak sesuai dengan sila-sila Pancasila.

Pentingnya Pancasila sebagai ideologi Negara adalah untuk memperlihatkan peran ideologi sebagai penuntun moral dalam kehidupan berbangsa dan bernegara sehingga ancaman-ancaman yang datang untuk negeri ini dapat dicegah dengan cepat. Sebab Pancasila merupakakan Ideologi yang terbuka bagi selur perkembanga zaman. Sehigga apapun yang terjadi dalam perkembangan zaman harus sesuai dengan kaedah-kaedah yang berlaku atas dasar Pancasila.

\section{Tantangan Pancasila Sebagai Ideologi Negara}

Pancasila sebagai ideologi negara dalam masa pemerintahan Presiden Soekarno, ideologi Pancasila mengalami pasang surut karena dicampur dengan ideologi komunisme dalam konsep Nasakom. Pancasila sebagai ideologi dalam masa pemerintahan Presiden Soeharto,ideologi,Pancasilamenjadi asas tunggal bagi semua organisasi politik (Orpol) dan organisasi masyarakat (Ormas).

Pada masa era reformasi,Pancasila sebagai ideologi negara mengalami pasang surut dengan ditandai beberapa hal, seperti: enggannya para penyelenggara negara mewacanakan tentang Pancasila, bahkan berujung pada 
hilangnya Pancasila dari kurikulum nasional, meskipun pada akhirnya timbul kesadaran penyelenggara negara tentang pentingnya pendidikan Pancasila di perguruan tinggi.

Di tengah perubahan zaman, persoalan yang perlu diwaspadai adalah ketika masyarakat, khususnya generasi muda, tidak lagi memandang Pancasila sebagai ideologi dan dasar negara. Dan pada era globalisasi tantangan pancasila sebagai ideologi negara adalah banyaknya ideologi alternatif melalui media informasi yang mudah dijangkau oleh seluruh anak bangsa seperti radikalisme, ekstremisme, konsumerisme. Hal tersebut juga membuat masyarakat mengalami penurunan intensitas pembelajaran Pancasila dan juga kurangnya efektivitas serta daya tarik pembelajaran Pancasila. Kemudian tantangan selanjutnya adalah eksklusivisme sosial yang terkait derasnya arus globalisasi yang mengarah kepada menguatnya kecenderungan politisasi identitas, gejala polarisasi dan fragmentasi sosial yang berbasis SARA. Bonus demografi yang akan segera dinikmati Bangsa Indonesia juga menjadi tantangan tersendiri untuk menanamkan nilai-nilai Pancasila kepada generasi muda di tengah arus globalisasi.

Unsur-unsur yang memengaruhi tantangan terhadap Pancasila sebagai ideologi negara meliputi faktor eksternal dan internal.

Adapun faktor eksternal meliputi hal-hal berikut:

- Pertarungan ideologis antara negara-negara super powerantara Amerika Serikat dan Uni Soviet antara 1945 sampai 1990 yang berakhir dengan bubarnya negara Soviet sehingga Amerika menjadi satu-satunya negara super power.

- Menguatnya isu kebudayaan global yang ditandai dengan masuknya berbagai ideologiasing dalam kehidupan berbangsa dan bernegara karena keterbukaan informasi.

- Meningkatnya kebutuhan dunia sebagai akibat pertambahan penduduk dan kemajuan teknologi sehingga terjadi eksploitasi terhadap sumber daya alam secara masif. Dampak konkritnya adalah kerusakan lingkungan,seperti banjir, kebakaran hutan.

- Globalisasi yang membawa budaya luar masuk ke Indonesia yang tidak 
sesuai dengan kepribadian bangsa.

Adapun faktor internal sebagai berikut:

- Pergantian rezim yang berkuasa melahirkan kebijakan politik yang berorientasi pada kepentingan kelompok atau partai sehingga ideologi Pancasilasering terabaikan.

- Penyalahgunaan kekuasaan (korupsi) mengakibatkan rendahnya kepercayaan masyarakat terhadap rezim yang berkuasa sehingga kepercayaan terhadap ideologi menurun drastis.

Dengan tantangan pancasila yang semakin berat, generasi bangsa diharapakan mampu menjaga dan mempertahankan Pancasila sebagi ideologi negara. Generasi bangsa dapat mempertahankan ideologi Pancasila dengan cara konsisten mengamalkan nilai-nilai Pancasila dalam kehidupan sehari-hari. Sila Ketuhanan Yang Maha Esa dapat diwujudkan dengan toleransi terhadap orang lain yang memiliki keyakinan yang berbeda. Kemanusiaan yang adil dan beradab dapat diwujudkan dalam bentuk perilaku saling menghargai martabat sesama manusia dan tidak melakukan diskriminasi. Sila Persatuan Indonesia tercermin dalam sikap gotong royong dan usaha untuk menciptakan kerukunan. Sedangkan sila Kerakyatan yang dipimpin oleh hikmat kebijaksanaan dalam permusyawaratan/perwakilan dapat Anda amalkan misalnya dengan menyelesaikan masalah melalui musyawarah. Sementara itu, sila Keadilan sosial bagi seluruh rakyat Indonesia dapat diwujudkan dalam bentuk perilaku menghargai hak orang lain serta melaksanakan kewajiban.

Pancasila sebagai ideologi, selain menghadapi tantangan dari ideologi-ideologi besar dunia juga menghadapi tantangan dari sikap dan perilaku kehidupan yang menyimpang dari norma-norma masyarakat umum. Tantangan itu meliputi, antara lain terorisme dan narkoba. Sebagaimana yang telah diinformasikan oleh berbagai media masa bahwa terorisme dan narkoba merupakan ancaman terhadap keberlangsungan hidup bangsa Indonesia dan ideologi negara. Beberapa unsur ancaman yang ditimbulkan oleh aksi terorisme, antara lain:

a. Rasa takut dan cemas yang ditimbulkan oleh bom bunuh diri mengancam keamanan negara dan masyarakat pada umumnya. 
b. Aksi terorisme dengan ideologinya menebarkan ancaman terhadap kesatuan bangsa sehingga mengancam disintegrasi bangsa.

c. Aksi terorisme menyebabkan investor asing tidak berani menanamkan modal di Indonesia dan wisatawan asing enggan berkunjung ke Indonesia sehingga mengganggu pertumbuhan perekonomian negara. Berikut ini gambar yang mencerminkan tentang terorisme.

Beberapa unsur ancaman yang ditimbulkan oleh penyalahgunaan narkoba meliputi hal-ha

A.Penyalahgunaan narkoba di kalangan generasi muda dapat merusak masa depan mereka sehingga berimplikasi terhadap keberlangsungan hidup bernegara di Indonesia.

b. Perdagangan dan peredaran narkoba di Indonesia dapat merusak reputasi negara Indonesia sebagai negara yang berlandaskan pada nilai-nilai Pancasila.

c. Perdagangan narkoba sebagai barang terlarang merugikan sistem perekonomian negara Indonesia karena peredaran ilegal tidak sesuai dengan peraturan perundangundangan.

- 2 contoh kasus yang menjadi tantangan Pancasila sebagai ideologi negara pada saat sekarang ini dan solusinya sebagai mahasiswa dan masyarakat

Ancaman non-militer dan juga globalisasi adalah sebuah hal yang dimana akan saling berkaitan dikarenakan akan sangat banyak berbagaimacam ancaman yang berasal dari luar baik itu untuk wilayah barat dan timur sekalipun pasti akan memberikan sebuah ancaman dimana ancaman tersebut akan memberikan sebuah masalah ke dalam suatu negara. Sebagaimana sebuah negara yang memulai akan adanya sebuah proses globalisasi yang dimana menjadi trend center bagi kaum millenial pada saat ini menjadi sebuah ancaman yang dimana akan membuat generasi ada suatu negara khususnya Indonesia sendiri akan menjadi kehilangan jati dirinya, karena akan membuat kaum milenial tersebut akan semakin meninggalkan kebudayaan serta kearifan lokal yang dimana lebih cocok untuk digunakan di negara Indonesia sendiri daripada lebih mengikuti gaya dari luar yang dimana merupakan hasil pengaruh dari globalisasi. Selain itu, contoh yang dapat muncul dari efek globalisasi adalah terdapatnya berbagaimacam tarian luar negeri yang lebih banyak diingat oleh kalangan muda daripada tarian yang berasal dari dalam negeri yang 
dimana tarian tersebut adalah sebuah tarian yang sudah berumus sangat tua, selain bentuk dari gaya maupun pose dari foto yang dilakukan, dan seperti kegiatan yang dimana mencari sebuah sensasi. Oleh sebab itu, maka pengaruh dari ancaman nonmiliter terhadap adanya globalisasi adalah salah satu ancaman yang sangat membawa banyak efek buruk.

Dalam hal tersebut, kita dapat menyelesaikan permasalahannya dengan melakukan pendidikan kewarganegaraan dan juga bela negara.

\section{Penjelasan bela negara.}

Upaya dari kegiatan untuk bela negara adalah sebuah kegiatan yang dimana dilakukan oleh para warga negara yang dimana berada dalam berbagaibidang tanpa memerhatikan latar belakang dari orang-orang tersebut yang dimana sesuai dengan status dari kependudukan, tugas dan juga berbagaimacam dari bentuk tanggung jawab yang dimiliki oleh masing-masing orang. Kemudian, pembelaan terhadap negara ini dianggap sangat penting dikarenakan untuk menghentikan berbagaimacam bentuk ancaman fisik dan juga non fisik yang dimana dapat dimiliki pada sebuah negara baik dalam bentuk miiliter dan juga non militer dikarenakan dalam ancaman tersebut biasanya dapat berasal dari dalam maupun luar negeri itu sendiri.

Upaya bela negara sebenarnya berada dalam pasa 9 ayat (1) UU RI No.3 Tahun 2002 yang dimana pada pasal tersebut menyebutkan bahwa dari pengertian dari bela negara itu sendiri adalah sebuah sikap dan juga sebuah perilaku yang dimana dimiliki warga negara yang dimana dijiwai oleh sebuah cinta terhadap tanah air yang dimana berdasarkan UUD 1945 yang dimana berusah untuk menjamin terjalannya sebuah kehidupa yang berbangsa dan bernegara.

Selain itu, bentuk dari bela negara bukanlah hanya sebuah kebutuhan, tetapi sebuah kewajiban dasar yang dimana terdapat pada manusia yang dimana dalam hal ini adalah sebuah bentuk kehormatan yang dimana diberikan kepada setiap warga negara tersebut apabila warga negara tersebut telah menjalankan bela negara yang dimana sesuai dengan kesadaran, tanggung jawab, dan juga rela berkorban dalam mengabdi untuk N;gara Kesatuan Republik Indonesia sehingga akan menjadi lebih 
kembali ke pada kebudayaannya sendiri dan tidak terlalu banyak termakan kebudayaan yang dimana berasal dari luar.

- Bentuk bentuk tantangan yang dihadapi pancasila sebagai ideologi negara yang datang dari dalam negri maupun luar negri

\section{A. Hambatan}

Hambatan muncul karena adanya perbedaan aliran pemikiran, misalnya:

a.) Paham individualistis. Negara adalah masyarakat hukum yang disusun atas kontrak semua individu dalam masyarakat. Disini kepentingan harkat dan martabat manusia dijunjung tinggi. Hak kebebasan individu hanya dibatasi oleh hak yang sama yang dimiliki individu lain, bukan oleh kepentingan masyarakat.

b.) Paham golongan (Class Theory). Negara adalah suatu susunan golongan (kelas) untuk menindas kelas lain. Paham ini berhubungan dengan paham materialisme sejarah (suatu ajaran yang bertitik tolak pada hubungan-hubungan produksi dan kepemilikan sarana produksi serta berakibat pada munculnya dua kelas yang bertentangan, kelas buruh dan kelas majikan dan semua itu terjadi dan berada dalam sejarah kehidupan manusia).

B.) Bentuk-Bentuk Ancaman

a.) Isu, penyebaran berita bohong dan fitnah atau desas desus dengan tujuan tertentu.

b.) Gejala-gejala negative, antara lain pola hidup konsumtif, sikaP , mental, individualistis, pemaksaan kehendak, kemalasan, penurunan, disiplin dan lain -lain

c.) Perbuatan dan tingkah laku yang mengganggu dan melanggar hukum.

d.) Subversi (sabotase, spionase, dan lain-lain).

\section{PENUTUP}

Dari pembahasan diatas dapat ditarik kesimpulan pancasila sebagai ideologi negara 
artinya seluruh warga negara Indonesia menjadikan pancasila sebagai dasar sistem kenegaraan. Pada hakikatnya pancasila sebagai dasar negara memiliki 3 dimensi yaitu: dimensi realitas, idealitas dan flesibilitas. Dan tantangan pancasila dari zaman ke zaman yang semakin berat, generasi bangsa diharapakan mampu menjaga dan mempertahankan Pancasila sebagi ideologi negara dengan cara mengamalkan nilainilai pancasila dalam kehidupan sehari-hari.

Dan dari pembahasan diatas dapat juga disimpulkan bahwa tantangan pancasila sebagai ideologi negara sangat mengancam kedaulatan negara .Oleh sebab itu Generasi muda sebagai generasi penerus bangsa diharapkan membawa perubahan yang lebih baik bagi bangsa ini dengan berpedoman pada Pancasila, akan tetapi para pemuda saat ini kian jauh dari nilai-nilai Pancasila.sebagai bangsa Indonesia yang memiliki Ideologi Pancasila,harus memahami apa arti dari Pancasila itu sendiri. Dengan demikian, mahasiswa mampu memberikan kontribusi yang konstruktif dalam bermasyarakat, berbangsa, dan bernegara, dengan mengacu kepada nilai-nilai Pancasila.

- Saran

Berdasarkan kesimpulan yang telah diuraikan diatas, maka penulis memberikan saran sebagai berikut:

Kepada mahasiswa disarankan untuk lebih meningkatkan kesadaran akan menerapkan nilai-nilai Pancasila agar sikap yang dilakukan para mahasiswa dapat sesuai dengan menciptakan manusia yang berjiwa Pancasila dan senantiasa menjadi mahasiswa yang berguna bagi bangsa dan Negara Indonesia. 
Darmini Roza dan Laurensius Arliman S Peran Pemerintah Daerah Di Dalam Melindungi Hak Anak Di Indonesia, Masalah-Masalah Hukum, Volume 47, Nomor 1, 2018.

Laurensius Arliman S, Komnas HAM dan Perlindungan Anak Pelaku Tindak Pidana, Deepublish, Yogyakarta, 2015.

Laurensius Arliman S, Penguatan Perlindungan Anak Dari Tindakan Human Trafficking Di Daerah Perbatasan Indonesia, Jurnal Selat, Volume 4, Nomor 1, 2016.

Laurensius Arliman S, Problematika Dan Solusi Pemenuhan Perlindungan Hak Anak Sebagai Tersangka Tindak Pidana Di Satlantas Polresta Pariaman, Justicia Islamica, Volume 13, Nomor 2, 2016.

Laurensius Arliman S, Pelaksanaan Perlindungan Anak Yang Tereksploitasi Secara Ekonomi Oleh Pemerintah Kota Padang, Veritas et Justitia, Volume 2, Nomor 1, 2016.

Laurensius Arliman S, Kedudukan Ketetapan MPR Dalam Hierarki Peraturan Perundang-Undangan Di Indonesia, Lex Jurnalica, Volume 13, Nomor 3, 2016.

Laurensius Arliman S, Komnas Perempuan Sebagai State Auxialiary Bodies Dalam Penegakan Ham Perempuan Indonesia, Justicia Islamica, Volume 14, Nomor 2, 2017.

Laurensius Arliman S, Peranan Pers Untuk Mewujudkan Perlindungan Anak 
Berkelanjutan Di Indonesia, Jurnal Ilmu Hukum Tambun Bungai, Volume 2, Nomor 2, 2017.

Laurensius Arliman S, Mewujudkan Penegakan Hukum Yang Baik Untuk Mewujudkan Indonesia Sebagai Negara Hukum, Jurnal Hukum Doctrinal, Volume 2, Nomor 2, 2017.

Laurensius Arliman S, Participation Non-Governmental Organization In Protecting Child Rights In The Area Of Social Conflict, The 1st Ushuluddin and Islamic Thought International Conference (Usicon), Volume 1, 2017.

Laurensius Arliman S, Partisipasi Masyarakat Dalam Pembentukan Perundang- Undangan Untuk Mewujudkan Negara Kesejahteraan Indonesia, Jurnal Politik Pemerintahan Dharma Praja, Volume 10, Nomor 1, 2017, https://doi.org/10.33701/jppdp.v10i1.379.

Laurensius Arliman S, Peran Komisi Perlindungan Anak Indonesia Untuk Mewujudkan Perlindungan Anak, Jurnal Respublica Volume 17, Nomor 2, 2018.

Laurensius Arliman S, Menjerat Pelaku Penyuruh Pengrusakan Barang Milik Orang Lain Dengan Mempertimbangkan Asas Fungsi Sosial, Jurnal Gagasan Hukum, Volume 1, Nomor 1, 2019.

Laurensius Arliman S, Ilmu Perundang-Undangan Yang Baik Untuk Negara Indonesia, Deepublish, Yogyakarta, 2019.

Laurensius Arliman S, Isdal Veri, Gustiwarni, Elfitrayenti, Ade Sakurawati, Yasri, 
Pengaruh Karakteristik Individu, Perlindungan Hak Perempuan Terhadap Kualitas Pelayanan Komnas Perempuan Dengan Kompetensi Sumber Daya Manusia Sebagai Variabel Mediasi, Jurnal Menara Ekonomi: Penelitian dan Kajian Ilmiah Bidang Ekonomi, Volume 6, Nomor 2, 2020.

Laurensius Arliman S, Pendidikan Kewarganegaraan, Deepublish, Yogyakarta, 2020.

Laurensius Arliman S, Makna Keuangan Negara Dalam Pasal Pasal 23 E UndangUndang Dasar 1945, Jurnal Lex Librum, Volume 6, Nomor 2 Juni 2020, http://dx.doi.org/10.46839/lljih.v6i2.151.

Laurensius Arliman S, Kedudukan Lembaga Negara Independen Di Indonesia Untuk Mencapai Tujuan Negara Hukum, Kertha Semaya Journal Ilmu Hukum, Volume 8, Nomor 7, 2020.

Laurensius Arliman S, Pelaksanaan Assesment Oleh Polres Kepulauan Mentawai Sebagai Bentuk Pelaksanaan Rehabilitasi Bagi Pecandu Dan Korban Penyalahgunaan Narkotika, Jurnal Muhakkamah, Volume 5, Nomor 1, 2020.

Laurensius Arliman S, Aswandi Aswandi, Firgi Nurdiansyah, Laxmy Defilah, Nova Sari Yudistia, Ni Putu Eka, Viona Putri, Zakia Zakia, Ernita Arief, Prinsip, Mekanisme Dan Bentuk Pelayanan Informasi Kepada Publik Oleh Direktorat Jenderal Pajak, Volume 17, No Nomor, 2020.

Larensius Arliman S, Koordinasi PT. Pegadaian (Persero) Dengan Direktorat Reserse Narkoba Polda Sumbar Dalam Penimbangan Barang Bukti Penyalahgunaan Narkotika, UIR Law Review, Volume 4, Nomor 2, 2020, https://doi.org/10.25299/uirlrev.2020.vol4(1).3779. 
Laurensius Arliman S, Tantangan Pendidikan Kewarganegaraan Pada Revolusi 4.0, Ensiklopedia Sosial Review, Volume 2, Nomor 3, 2020.

Muhammad Afif dan Laurensius Arliman S, Protection Of Children's Rights Of The Islamic And Constitutional Law Perspective of The Republic Of Indonesia, Proceeding: Internasional Conference On Humanity, Law And Sharia (Ichlash), Volume 1, Nomor 2, 2020.

Otong Rosadi danLaurensius Arliman S, Urgensi Pengaturan Badan Pembinaan Idelogi Pancasila Berdasarkan Undang-Undang Sebagai State Auxiliary Bodies yang Merawat Pancasila dalam Perspektif Hak Asasi Manusia, Prosiding Konferensi Nasional Hak Asasi Manusia, Kebudayaan dan Tujuan Pembangunan Berkelanjutan Indonesia pada Masa Pandemi Covid-19: Tantangan untuk Keilmuan Hukum dan Sosial Volume 1, Universitas Pancasila, Jakarta, 2020. 